\title{
Activation of NLRP3 Inflammasome Complexes by Beta-Tricalcium Phosphate Particles and Stimulation of Immune Cell Migration in vivo
}

\author{
Kouji Maruyama ${ }^{a}$ Jin-Yan Cheng ${ }^{b}$ Hidee Ishii ${ }^{a}$ Yu Takahashia \\ Vincent Zangiacomi ${ }^{c}$ Takatomo Satoh ${ }^{b}$ Tetsuji Hosono $^{d}$ Ken Yamaguchi ${ }^{\mathrm{e}}$ \\ ${ }^{a}$ Experimental Animal Facility, Shizuoka Cancer Center Research Institute, Shizuoka, Japan; ${ }^{\mathrm{b}}$ Advanced Analysis \\ Technology Department, Corporate R\&D Center, Olympus Corporation, Tokyo, Japan; 'Regional Resource Division, \\ Shizuoka Cancer Center Research Institute, Shizuoka, Japan; 'Laboratory of Medicinal Microbiology, Yokohama \\ College of Pharmacy, Yokohama, Japan; eShizuoka Cancer Center Hospital and Research Institute, Shizuoka, Japan
}

\section{Keywords}

Beta-tricalcium phosphate $\cdot$ Inflammasome $\cdot$ Dendritic cell . Macrophage $\cdot$ THP-1 cell $\cdot$ Immunomodulation findings suggest that the effects of $\beta$-TCP particles in vivo are at least partly mediated by NLRP3 inflammasome complexes.

(C) 2021 The Author(s).

Published by S. Karger AG, Basel

\begin{abstract}
Beta-tricalcium phosphate ( $\beta$-TCP) serves as a bone substitute in clinical practice because it is resorbable, biocompatible, osteointegrative, and osteoconductive. Particles of $\beta$-TCP are also inflammatory mediators although the mechanism of this function has not been fully elucidated. Regardless, the ability of $\beta$-TCP to stimulate the immune system might be useful for immunomodulation. The present study aimed to determine the effects of $\beta$-TCP particles on NLR family pyrin domain containing 3 (NLRP3) inflammasome complexes. We found that $\beta$-TCP activates NLRP3 inflammasomes, and increases interleukin (IL)-1 $\beta$ production in primary cultured mouse dendritic cells (DCs) and macrophages, and human THP-1 cells in caspase- 1 dependent manner. In THP-1 cells, $\beta$-TCP increased also IL-18 production, and NLRP3 inflammasome activation by $\beta$-TCP depended on phagocytosis, potassium efflux, and reactive oxygen species (ROS) generation. We also investigated the effects of $\beta$-TCP in wild-type and NLRP3-deficient mice in vivo. Immune cell migration around subcutaneously injected $\beta$-TCP particles was reduced in NLRP3-deficient mice. These
\end{abstract}

karger@karger.com www.karger.com/jin

Karger!"
C 2021 The Author(s).

Published by S. Karger AG, Basel

This is an Open Access article licensed under the Creative Commons Attribution-NonCommercial-4.0 International License (CC BY-NC) (http://www.karger.com/Services/OpenAccessLicense), applicable to the online version of the article only. Usage and distribution for commercial purposes requires written permission.

\section{Introduction}

The calcium phosphate ceramic beta-tricalcium phosphate $(\beta-\mathrm{TCP})$ is a fully resorbable, biocompatible, osteointegrative, and osteoconductive material [1-6]. The Japanese Ministry of Health, Labor, and Welfare has approved $\beta$-TCP as a medical device, and it is clinically applied as a bone replacement material in clinical oncology and other fields. The biocompatibility of metal parts of prostheses has been improved by coating with hydroxyapatite (HA), which is closely related to $\beta$-TCP. However, calcium phosphate ceramics induce cellular inflammatory responses [7]. The biological activities of these ceramics, including inflammatory mediation, are influenced by physicochemical properties such as stoichiometry, crystallinity, and solubility [8-13].

Materials with inflammatory properties are thought to be adverse as bone substituents or coating materials; however, extensive studies of the immunostimulatory potential of ceramics such as HA have shown that they could 
function as immunomodulators or vaccine adjuvants [14-22]. We previously showed that $\beta$-TCP particles evoked the migration of mouse immune cells in vivo and stimulated mouse J774A.1 monocyte/macrophage cells phenotypically and functionally in vitro [23]. We also showed that $\beta$-TCP particles enhanced the expression of surface molecules including costimulators and MHC class I and class II molecules and of several cytokines and chemokines in primary cultured mouse dendritic cells (DCs) and macrophages. The $\beta$-TCP particles also caused a significant reduction in antigen uptake by DCs, and conditioned medium from $\beta$-TCP-treated DCs facilitated the migration of splenocytes in transwell migration assays [24]. These findings indicated that $\beta$-TCP induces the phenotypic and functional maturation and activation of primary cultured DCs and macrophages.

Inflammasomes are molecular platforms that are activated upon cellular infection or stress that triggers the maturation and secretion of proinflammatory cytokines, such as IL-1 $\beta$ and IL-18, which engage innate immune defenses [25]. Inflammasomes are categorized into nucleotide-binding oligomerization domain-like receptor (NLR) and absent in melanoma-2 (AIM2) classes of protein complexes according to their pattern recognition receptors (PRRs) $[26,27]$. The PRRs of NLR inflammasomes include NLRP1, NLRP3, and NLR family caspase activation and recruitment domain (CARD) containing 4 (NLRC4) subsets, among which NLRP3 inflammasomes have been characterized; they consist of an NLRP3 scaffold, apoptosis-associated speck-like protein containing a caspase recruit domain (ASC), and caspase-1 [25].

NLRP3 is activated upon exposure to whole pathogens, as well as many structurally diverse pathogen-associated molecular patterns (PAMPs), host-derived danger signals (danger-associated molecular patterns, DAMPs), and environmental irritants [25]. Upon NLRP3 activation, NLRP3 oligomerization leads to pyrin domain (PYD) clustering and presentation for homotypic interaction with the ASC adapter containing a PYD and a CARD that in turn recruits the CARD of pro-caspase- 1 . Pro-caspase-1 clustering permits autocleavage and the formation of active caspase- 1 p10/p20 tetramers that processes cytokine pro-forms of molecules such as IL- $1 \beta$ to generate active molecules [25]. However, phagocytosis $[28,29]$, potassium efflux [30-35], and ROS production $[30-33,36,37]$ are needed to activate inflammasome complexes.

The present study aimed to determine the effects of $\beta$-TCP particles on NLRP3 inflammasome complexes. Although the effects of HA [21, 38,39], octacalcium phosphate [40], and basic calcium phosphate (a mixture of octacalcium phosphate, HA, carbonate-substituted, and TCP) [40] on the NLRP3 inflammasome have been determined, the effects of pure $\beta$-TCP alone remain unknown. The effects of $\beta$-TCP on inflammasomes are important to understand before it could be characterized and developed as a novel immunomodulator and/or vaccine adjuvant.

\section{Materials and Methods}

\section{Preparation of $\beta-T C P$}

A fine powdered formulation of $\beta$-TCP with a 1 - to $50-\mu \mathrm{m}$ diameter was prepared by chemical synthesis followed by sintering at $1,000^{\circ} \mathrm{C}$ for $10 \mathrm{~h}$ (Olympus-Terumo Biomaterials, Tokyo, Japan) [23]. The size distribution of $\beta$-TCP particles was measured by granulometry using an SALD-2000J laser diffraction analyzer (Shimadzu, Kyoto, Japan). The mean diameter ( \pm standard deviation) of the particles was $5.37 \pm 0.34$, and $>90 \%$ of particles were in the range of $1-20 \mu \mathrm{m}$ with $d_{50}$ and $d_{90}$ values of $4.99 \mu \mathrm{m}$ and 16.32 $\mu \mathrm{m}$, respectively. The endotoxin-free powdered $\beta$-TCP was $>99 \%$ pure and suspended in phosphate-buffered saline (PBS) for experimental purposes.

\section{Reagents, Chemicals, and Antibodies}

Reagents were purchased or obtained from the indicated suppliers: media, supplements, fetal bovine serum (FBS), penicillinstreptomycin, and G418 (Thermo Fisher Scientific Inc., Waltham, MA, USA). Recombinant mouse granulocyte macrophage colonystimulating factor (GM-CSF), macrophage colony-stimulating factor (M-CSF), and anti-mouse IL-1 $\beta$ (R\&D Systems, Minneapolis, MN, USA). Monosodium urate (MSU) crystals, lipopolysaccharide ([LPS]; ultrapure grade from E. coli K12 strain), polyinosinic-polycytidylic acid (poly I:C), high molecular weight, phorbol myristate acetate (PMA), benzyloxycarbonyl-Val-Ala-Asp-fluoromethylketone (Z-VAD-fmk, a caspase inhibitor), hygromycin $\mathrm{B}$ (InvivoGen, San Diego, CA, USA), cytochalasin D (Merck Millipore, Billerica, MA, USA), potassium chloride (Wako Pure Chemical Industries, Osaka, Japan), (2R,4R)-4-aminopyrrolidine-2,4dicarboxylic acid (APDC), a selective agonist for group II metabolic glutamate receptors (Enzo Life Sciences, Farmingdale, NY, USA), ultrapure chicken ovalbumin (Hyglos GmbH, Bernried, Germany), anti-human IL-1 $\beta$ clone 3ZD (Biological Resources Branch, NCI, Frederick, MD, USA), anti-mouse caspase-1 p10 (M20), anti-human caspase-1 p10 (C-20; Santa Cruz Biotechnology, Dallas, TX, USA), and horse anti-mouse IgG antibody conjugated with horseradish peroxidase (HRP) (Cell Signaling Technology, Danvers, MA, USA).

\section{Mice and Implantation in vivo}

Male C57BL/6 (B6) mice aged 5-6 weeks (CLEA Japan, Tokyo, Japan) were acclimated for 1-2 weeks, and NLRP3-deficient mice (B6.129S6-Nlrp3tm1Bhk/J) (Jackson Laboratory, Bar Harbor, ME, USA) were maintained at the experimental animal facility of the Shizuoka Cancer Center Research Institute. The original NLRP3 deficient line was backcrossed with wild-type B6 mice for 10 generations and fixed. Wild-type and knockout genes were typed by 
PCR of tail tip genomic DNA, as described by the Jackson Laboratory.

Wild-type and NLRP3-deficient mice were implanted in vivo by the subcutaneous injection of a suspension of $100 \mu \mathrm{g}$ of fine $\beta$-TCP particles in PBS into the flank through a 26-gauge needle, as described [23]. Samples of skin and subcutaneous tissues surrounding the $\beta$-TCP injection sites and abdominal muscles were collected 3-14 days later and fixed in 10\% formaldehyde. Fixed tissues were decalcified in 5\% formic acid, embedded in paraffin, sectioned, stained with hematoxylin and eosin, and examined by microscopy.

\section{Preparation of Mouse DCs and Macrophages}

Bone marrow (BM) cells were harvested from the femurs and tibiae of B6 or NLRP3-deficient mice and filtered through a Falcon $40 \mu \mathrm{m}$ nylon cell strainer (BD Biosciences, San Jose, CA, USA). Red blood cells among the BM cells were destroyed using ACK lysing buffer (Life Technologies) then DCs and macrophages were derived from the $\mathrm{BM}$ cells.

We derived DCs from BM cells, as described [24]. In brief, BM cells $\left(3 \times 10^{6} / \mathrm{mL}\right)$ in RPMI 1640 medium supplemented with $5 \%$ FBS and $50 \mu \mathrm{M} 2$-mercaptoethanol were seeded into $75-\mathrm{cm}^{2}$ flasks and incubated at $37^{\circ} \mathrm{C}$ for $1.5 \mathrm{~h}$. Nonadherent cells $\left(1 \times 10^{6} / \mathrm{mL}\right)$ were collected, seeded, and incubated for 5 days along with 1,000 $\mathrm{U} / \mathrm{mL}$ of GM-CSF. CD11 $\mathrm{c}^{+}$cells were enriched from the culture using CD11c MicroBeads (Miltenyi Biotec, Bergisch Gladbach, Germany) with resulting purity $>90 \%$.

Macrophages were derived from BM cells, as described [24]. Mononuclear cells $\left(3 \times 10^{6} / \mathrm{mL}\right)$ fractioned from BM cells by density gradient centrifugation using Lympholyte-M (Cedarlane, Burlington, ON, Canada) were seeded into $25-\mathrm{cm}^{2}$ flasks and incubated for $24 \mathrm{~h}$ in EMEM containing $10 \mathrm{ng} / \mathrm{mL}$ M-CSF, 10\% FBS, and $15 \mathrm{mM}$ HEPES. Nonadherent cells were collected and seeded into $75-\mathrm{cm}^{2}$ flasks with $10 \mathrm{~mL}$ of the same fresh EMEM containing $10 \mathrm{ng} / \mathrm{mL}$ M-CSF. Macrophages were derived from these cells by incubation for 6 days. The purity of $\mathrm{CD}_{11 \mathrm{~b}^{+}}$macrophages was $>90 \%$.

\section{Human Monocytic THP-1 Cells and Genetically Engineered} Sublines

Human monocytic THP-1 cells (American Type Culture Collection, Manassas, VA, USA) were maintained in RPMI 1640 medium supplemented with $10 \% \mathrm{FBS}$ and $50 \mu \mathrm{M} 2$-mercaptoethanol and used in the experiments that generated the results shown in Figure 2 and online suppl. Figure 1; for all online suppl. material, see www.karger.com/doi/10.1159/000518953. The controls comprised the genetically engineered THP-1 cell lines, THP1-Null, THP1-defASC, and THP1-defNLRP3 (InvivoGen, San Diego, CA, USA) that were maintained in RPMI 1640 medium $(4.5 \mathrm{~g} / \mathrm{L}$ glucose, 10 mM HEPES) supplemented with $10 \%$ FBS and $200 \mu \mathrm{g} /$ mL hygromycin. The THP1-Null cells are mock transfected and fully competent for ASC and NLRP3 expression, whereas THP1defASC and THP1-defNLRP3 cells are deficient in ASC and NLRP3, respectively. These genetically engineered cells were used in the experiments that generated the results shown in Figure $5 b$.

In vitro Stimulation with $\beta-T C P$

Macrophages and the DCs derived from BM cells (both $1 \times 10^{6}$ / well) were seeded in 12-well plates with or without $5 \mathrm{ng} / \mathrm{mL}$ of LPS for $3 \mathrm{~h}$ then stimulated with 10 or $100 \mu \mathrm{g} / \mathrm{mL} \beta$-TCP or $100 \mu \mathrm{g} / \mathrm{mL}$ MSU for $4 \mathrm{~h}$.

The THP-1 and genetically modified THP-1 cells were differentiated using $0.5 \mu \mathrm{M}$ PMA for $3 \mathrm{~h}$ and were washed and seeded at a density of $5 \times 10^{5} / \mathrm{mL}$ each. The cells were washed 3 days later and stimulated with a relevant dose of $\beta$-TCP or MSU $(100 \mu \mathrm{g} / \mathrm{mL}$ each) for 4 or $6 \mathrm{~h}$, as described $[23,24]$. The cells were incubated with inhibitors $(20 \mu \mathrm{M} \mathrm{Z-VAD-fmk,} 2 \mu \mathrm{M}$ cytochalasin D, $100 \mathrm{mM}$ $\mathrm{KCl}$, or $100 \mu \mathrm{M}$ APDC) for $1 \mathrm{~h}$ then stimulated with $\beta$-TCP particles in some experiments. Thereafter, cytokine production was measured in cells and culture supernatants.

\section{Analysis of Cytokine Production}

We used ELISA kits to quantify mouse IL- $1 \beta$ and IL-18 in culture supernatants (R\&D Systems, Minneapolis, MN, USA) and human IL-1 $\beta$ and IL-18 (Thermo Fisher Scientific Inc., Waltham, MA, USA). The amounts of pro-IL- $1 \beta$ and pro-caspase- 1 in cell extracts, IL-1 $\beta$ (p17), and caspase-1 (p10) in culture supernatants were detected by Western blotting. Proteins in cell supernatants were precipitated using methanol/chloroform then reacted against anti-mouse IL- $1 \beta$, anti-human IL-1 $\beta$, anti-mouse caspase- 1 p10 (M-20), and anti-human caspase-1 p10 (C-20) (Santa Cruz Biotechnology, Dallas, TX, USA), followed by the secondary antibody, anti-mouse IgG conjugated with HRP.

\section{Statistical Analysis}

Results are shown as means \pm standard error of the mean. Differences between groups were analyzed using 2-way ANOVA followed by Tukey tests. Differences between 2 groups were considered statistically significant at $p<0.05$. Results shown in all figures are representative of 2-4 independent experiments and the numerical data used for Figures 1-3, 5, and 6 were shown in online suppl. Table 1.

\section{Results}

\section{$\beta$-TCP Induced IL-1 $\beta$ Production in LPS-Primed Macrophages and DCs}

In the first experiment, we assessed the activation of NLRP3 inflammasomes by $\beta$-TCP. Mouse BM-derived macrophages and DCs were primed with a low concentration $(5 \mathrm{ng} / \mathrm{mL})$ of LPS for $3 \mathrm{~h}$ then stimulated with $\beta$-TCP for $4 \mathrm{~h}$. We found that $\beta$-TCP induced a significant $(p<0.001)$ increase in the production of IL- $1 \beta$ in primed cells but not in those without LPS priming (Fig. 1). The results of mouse macrophages and DCs were similar.

We also assessed the effects of $\beta$-TCP on NLRP3 inflammasomes in human monocytic THP-1 cells. We differentiated the cells into macrophages using PMA then incubated them with $\beta$-TCP. Figure 2 a shows that $\beta$-TCP induced significant IL- $1 \beta$ production in the differentiated THP- 1 cells. Figure $2 \mathrm{~b}$ shows that $\beta$-TCP also induced significant $(p<0.001)$ IL-18 production, suggesting that $\beta$-TCP activates NLRP3 inflammasome complexes in 
Fig. 1. Effects of $\beta$-TCP particles on IL- $1 \beta$ production in primary cultured mouse bone marrow-derived macrophages or dendritic cells incubated with or without low-dose LPS. Cells were primed with $5 \mathrm{ng} /$ $\mathrm{mL}$ of LPS for $3 \mathrm{~h}$ and then stimulated with $\beta$-TCP for $4 \mathrm{~h}$. IL- $1 \beta$ concentrations in supernatants were assayed using ELISA. Production of IL-1 $\beta$ was significantly higher only in cells incubated with both LPS and $\beta$-TCP $(p<0.001$, Tukey tests $)$. $\beta$-TCP, beta-tricalcium phosphate; DCs, dendritic cells; LPS, lipopolysaccharide; BMMФ, bone marrow-derived macrophages; BMDC, bone marrow-derived dendritic cells.

Fig. 2. Effects of $\beta$-TCP particles on IL- $1 \beta$ (a) and IL-18 (b) production in PMA-differentiated human monocytic THP-1 cells. THP-1 cells were differentiated by PMA and incubated with $100 \mu \mathrm{g} / \mathrm{mL}$ of $\beta$-TCP or MSU for $4 \mathrm{~h}$. IL-1 $\beta$ and IL-18 concentrations in supernatants were assayed by ELISA. Values are shown as means \pm SEM of triplicate measurements. ${ }^{*} p<0.05,{ }^{* *} p<$ $0.01,{ }^{* * *} p<0.001$; symbols indicate significant differences by Tukey test. $\beta$-TCP, beta-tricalcium phosphate; MSU, monosodium urate; PMA, phorbol myristate acetate; SEM, standard error of the mean.
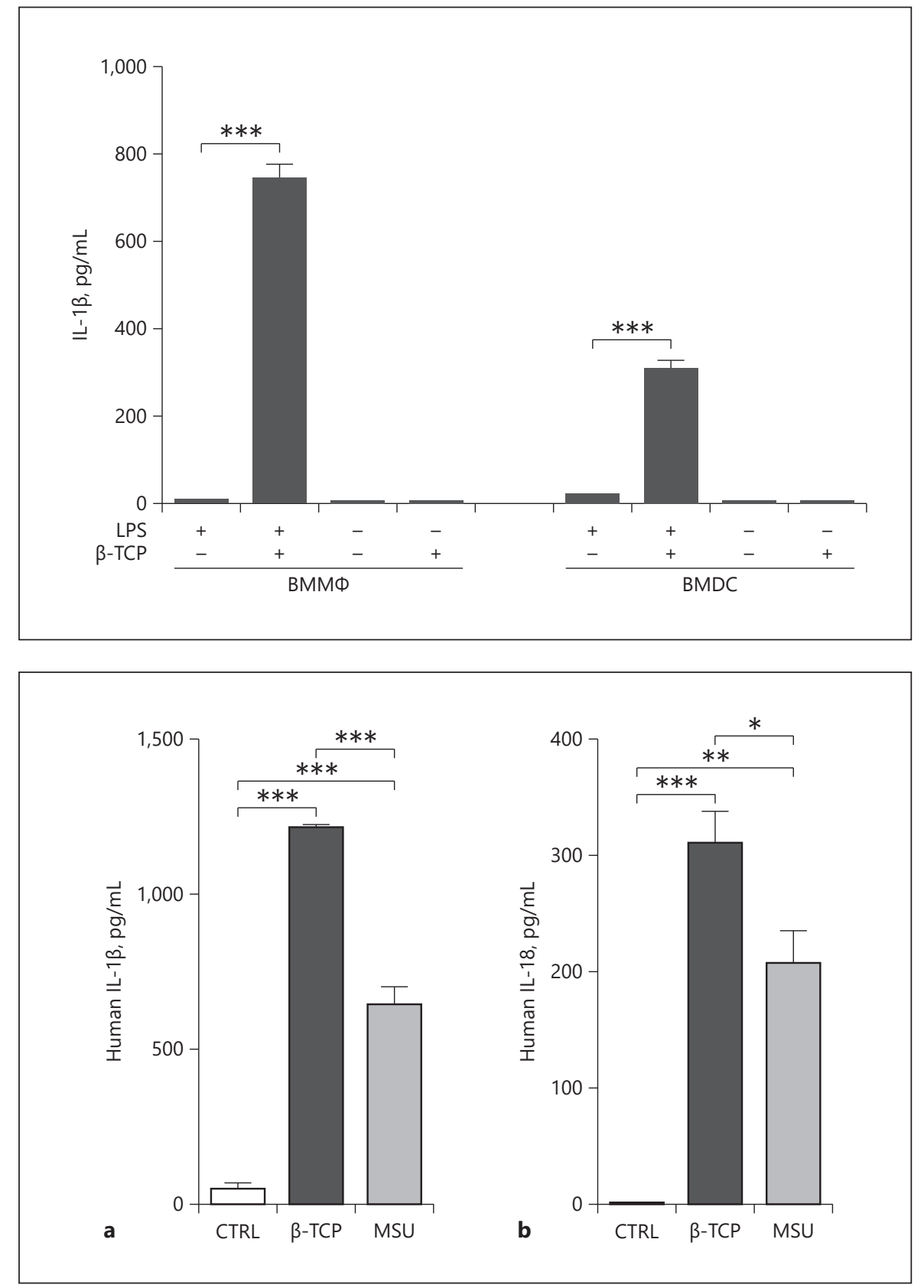

THP- 1 cells differentiated by PMA. However, $\beta$-TCP did not significantly induce IL-18 in mouse primary cultured DCs primed with LPS.

\section{$\beta$-TCP-Induced IL-1 $\beta$ Production Depended on Caspase-1 Activation}

The production of mature IL- $1 \beta$ depends on caspase- 1 activation $[41,42]$. We showed that $\beta$-TCP significantly increased IL- $1 \beta$ production in DCs (Fig. 3a) and macro- phages (Fig. 3b) primed with a low dose of LPS. LPSprimed DCs and macrophages were incubated in the presence or absence of caspase inhibitor Z-VAD-fmk (20 $\mu \mathrm{M})$ then stimulated by $\beta$-TCP. Z-VAD-fmk significantly $(p<0.001)$ inhibited IL-1 $\beta$ production in cells incubated with 2 doses of $\beta$-TCP. The results were similar in DCs and macrophages incubated with MSU. These findings indicated that $\beta$-TCP-induced IL- $1 \beta$ production is caspase-dependent. 


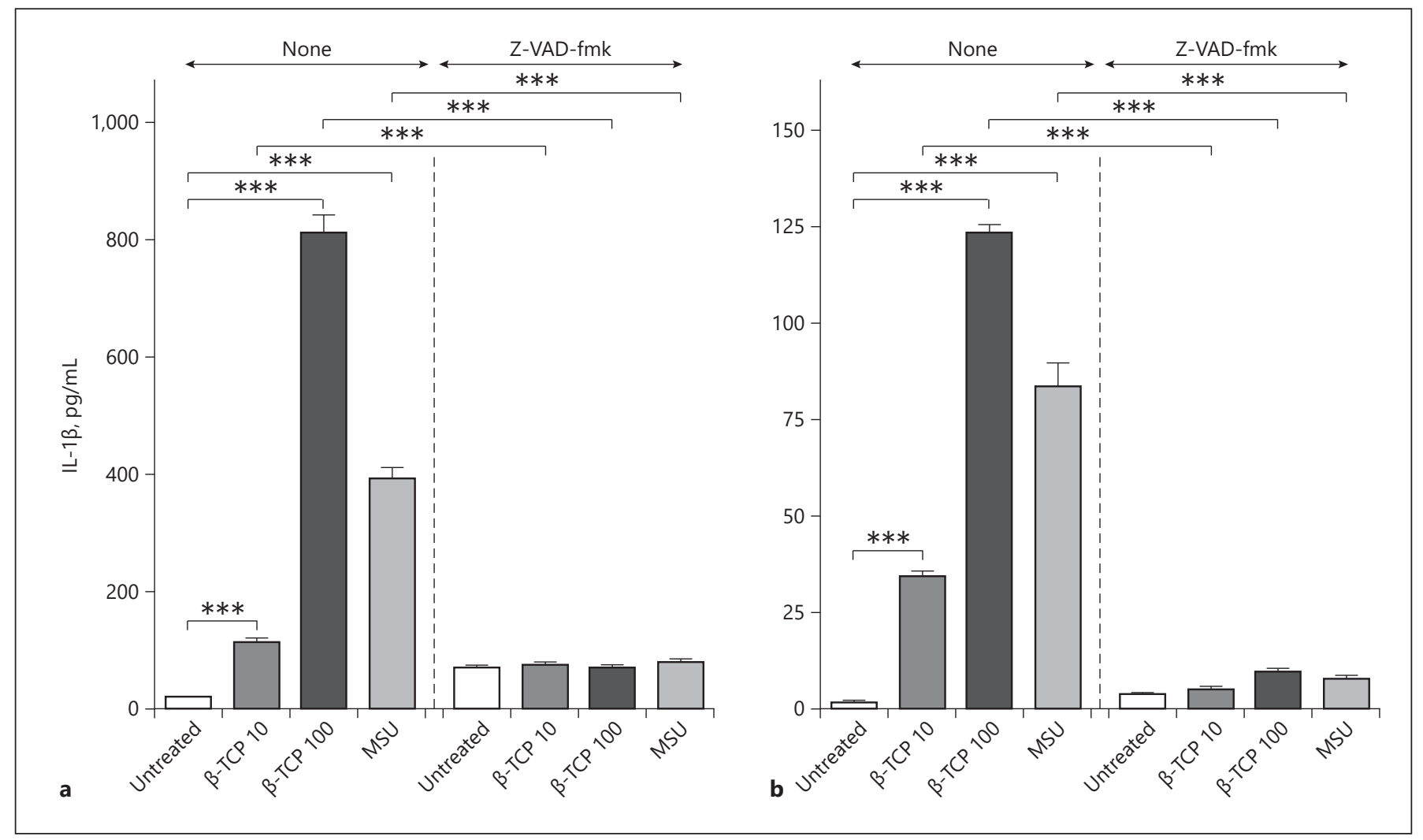

Fig. 3. Effects of caspase inhibitor Z-VAD-fmk on IL- $1 \beta$ production induced by $\beta$-TCP particles and $5 \mathrm{ng} / \mathrm{mL}$ (low-dose) LPS in primary cultured mouse DCs (a) and macrophages (b). Cells were primed with low-dose LPS for $3 \mathrm{~h}$ and then stimulated with $\beta$-TCP (10 or $100 \mu \mathrm{g} / \mathrm{mL})$ or MSU $(100 \mu \mathrm{g} / \mathrm{mL})$ with or without Z-VAD-fmk $(20$ $\mu \mathrm{M})$ for $4 \mathrm{~h}$. Interleukin- $1 \beta$ concentrations in supernatants were assayed by ELISA. Values are shown as means \pm SEM of triplicate wells. ${ }^{* * *} p<0.001$; significantly different (Tukey tests). $\beta$-TCP, betatricalcium phosphate; DCs, dendritic cells; MSU, monosodium urate; LPS, lipopolysaccharide; SEM, standard error of the mean.
We analyzed $\beta$-TCP-induced IL- $1 \beta$ production in LPSprimed macrophages by Western blotting. Pro-caspase-1 and pro-IL- $1 \beta$ accumulated in LPS-primed macrophages regardless of the presence or absence of the caspase inhibitor (Fig. 4; left and right panels), and $\beta$-TCP and MSU each caused the release of cleaved and active caspase-1 (p10) into the supernatant (Fig. 4, left panel). The cleaved, active form of IL- $1 \beta$ (p17) was detected after incubation with $100 \mu \mathrm{g} / \mathrm{mL}$ of either $\beta$-TCP or MSU, indicating that these active cytokines were produced by activated caspase-1 p10 (Fig. 4, left panel). Pro-caspase-1 and pro-IL$1 \beta$ were produced at comparable levels in cells cultured with and without the caspase inhibitor Z-VAD-fmk; but, activated caspase- 1 p10 was undetectable in supernatants from these cells. A thin band of IL- $1 \beta$ p17 was detected only in cells incubated with $100 \mu \mathrm{g} / \mathrm{mL} \beta$-TCP (Fig. 4, right panel). Biologically active IL- $1 \beta$ p17 was caspase1 -dependently produced after $\beta$-TCP stimulation. Online suppl. Figure 1 shows whole blots of human THP- 1 cells incubated with PMA- and $\beta$-TCP. Both IL- $1 \beta$ p 17 and caspase- 1 p10 were detected in supernatants from cells incubated with $100 \mu \mathrm{g} / \mathrm{mL}$ of $\beta$-TCP or MSU.

\section{$\beta$-TCP-Induced IL-1 $\beta$ Production in DCs Derived from NLRP3 Deficient Mice}

DCs derived from NLRP3-deficient mice were incubated with low-dose LPS and stimulated with $\beta$-TCP to determine whether $\beta$-TCP-induced IL- $1 \beta$ production requires the activation of NLRP3 inflammasomes. Incubation with $\beta$-TCP did not induce a significant increase in IL- $1 \beta$ secretion into the culture media of DCs from NLRP3-deficient mice (Fig 5a). Notably, DCs from NLRP3 heterozygotic mice produced IL- $1 \beta$ levels that were intermediate between wild-type and deficient mice (Fig 5a). These findings showed that NLRP 3 is required for $\beta$-TCPinduced IL- $1 \beta$ production in DCs. 
Fig. 4. $\beta$-TCP particles activate IL- $1 \beta$ cleavage and release in primary cultured mouse macrophages. Cells were primed with $5 \mathrm{ng} /$ $\mathrm{mL}$ of LPS for $3 \mathrm{~h}$ and then stimulated with $\beta$-TCP $(10$ or $100 \mu \mathrm{g} / \mathrm{mL})$ or MSU $(100 \mu \mathrm{g} /$ $\mathrm{mL})$ with or without Z-VAD-fmk $(20 \mu \mathrm{M})$ for $4 \mathrm{~h}$. Cell lysates (cell) and supernatants (SN) were analyzed by Western blotting. Supernatant proteins were concentrated by methanol/chloroform precipitation. Procaspase- 1 and pro-IL- $1 \beta$ were detected in cell lysates and their secreted/cleaved active forms (caspase- 1 p10 and IL- $1 \beta$ p17, respectively) were detected in supernatants. $\beta$-TCP, beta-tricalcium phosphate; MSU, monosodium urate; LPS, lipopolysaccharide; $\mathrm{SN}$, supernatants.

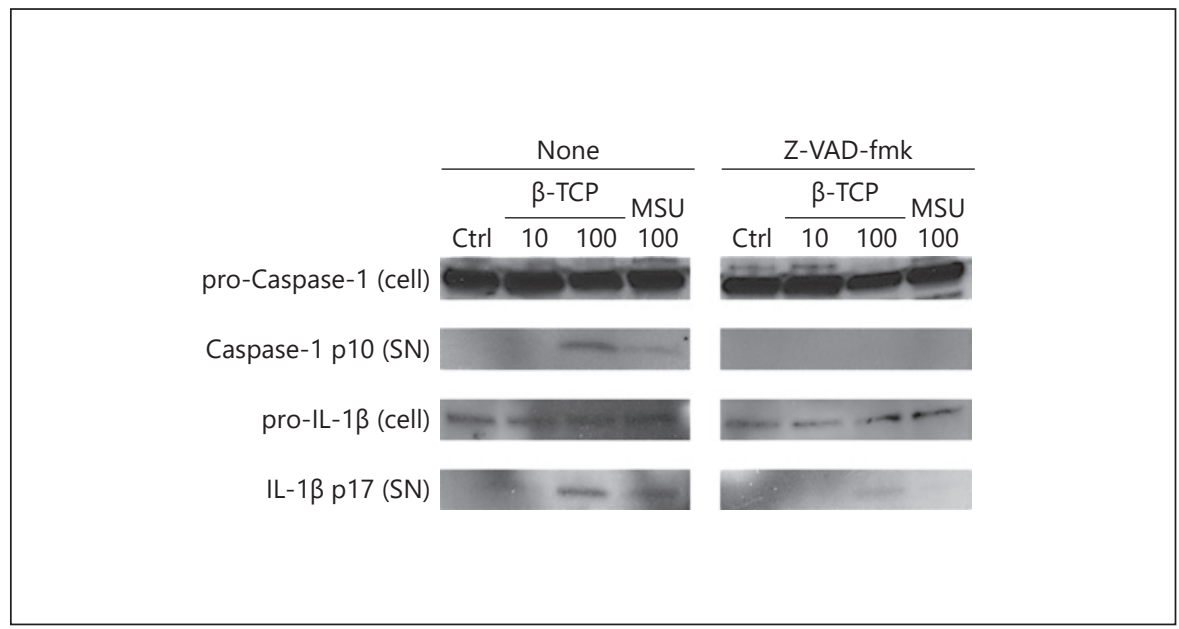

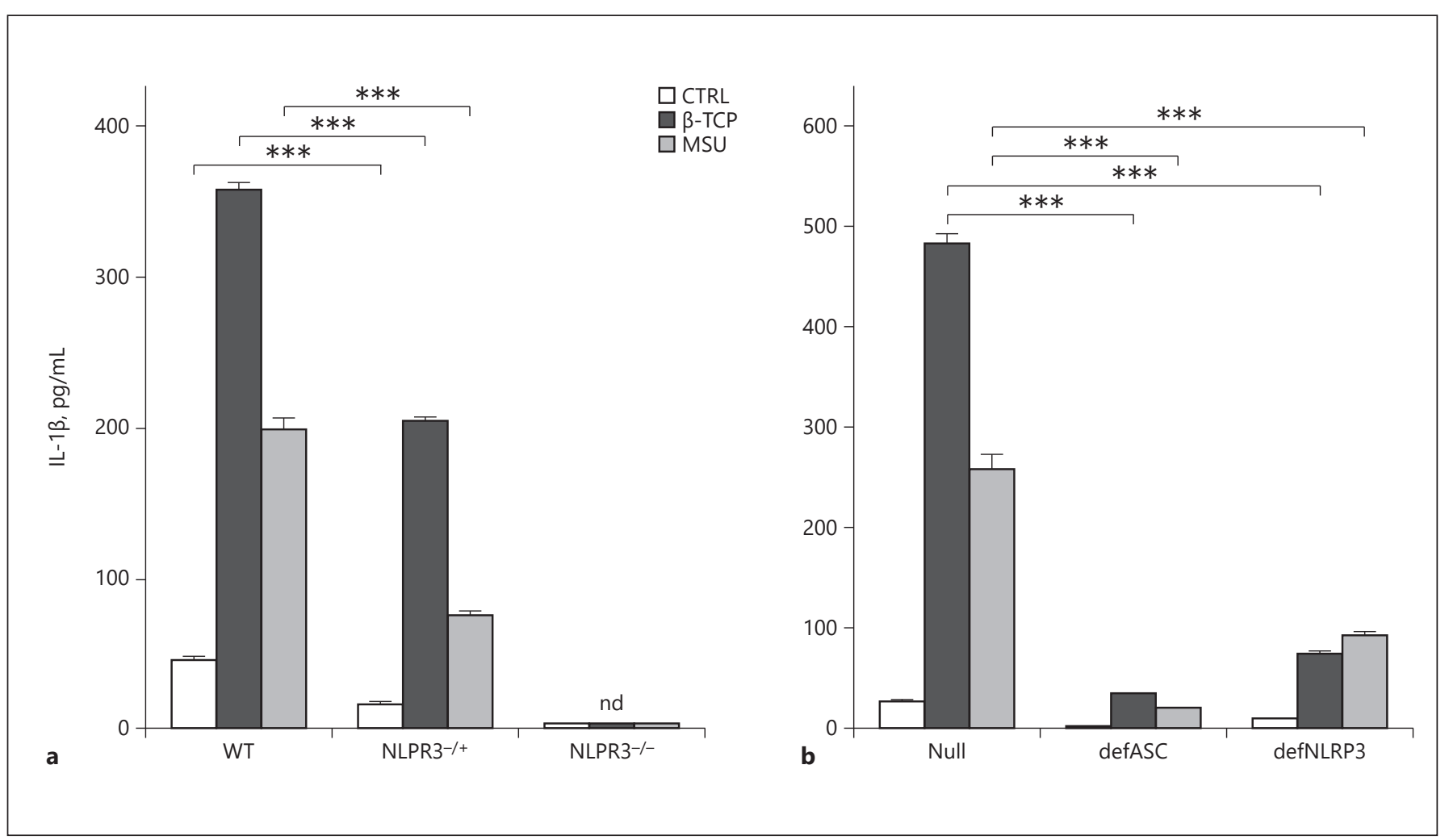

Fig. 5. Effects of $\beta$-TCP particles on IL- $1 \beta$ production in primary cultured mouse DCs derived from wild-type (WT), NLRP3 heterozygote $\left(\mathrm{NLRP}^{-/+}\right)$, and NLRP3 deficient $\left(\mathrm{NLRP}^{-/-}\right)$littermates and genetically engineered human THP-1 cells. a Primary cultured mouse DCs were primed with $5 \mathrm{ng} / \mathrm{mL}$ LPS for $3 \mathrm{~h}$ and then stimulated with $100 \mu \mathrm{g} / \mathrm{mL}$ of $\beta$-TCP or MSU for $4 \mathrm{~h}$. b Mock-transfected (Null), ASC deficient (defASC), and NLRP3 deficient (defNLRP3) human THP-1 cells incubated with PMA and then stimulated with $100 \mu \mathrm{g} / \mathrm{mL}$ of $\beta$-TCP or MSU for $4 \mathrm{~h}$. Interleukin- $1 \beta$ concentrations in supernatants were assayed by ELISA. Values are shown as means \pm SEM of triplicate values. ${ }^{* * *} p<0.001$; significantly different (Tukey tests). $\beta$-TCP, beta-tricalcium phosphate; DCs, dendritic cells; MSU, monosodium urate; LPS, lipopolysaccharide; PMA, phorbol myristate acetate; SEM, standard error of the mean; nd, not detected. 


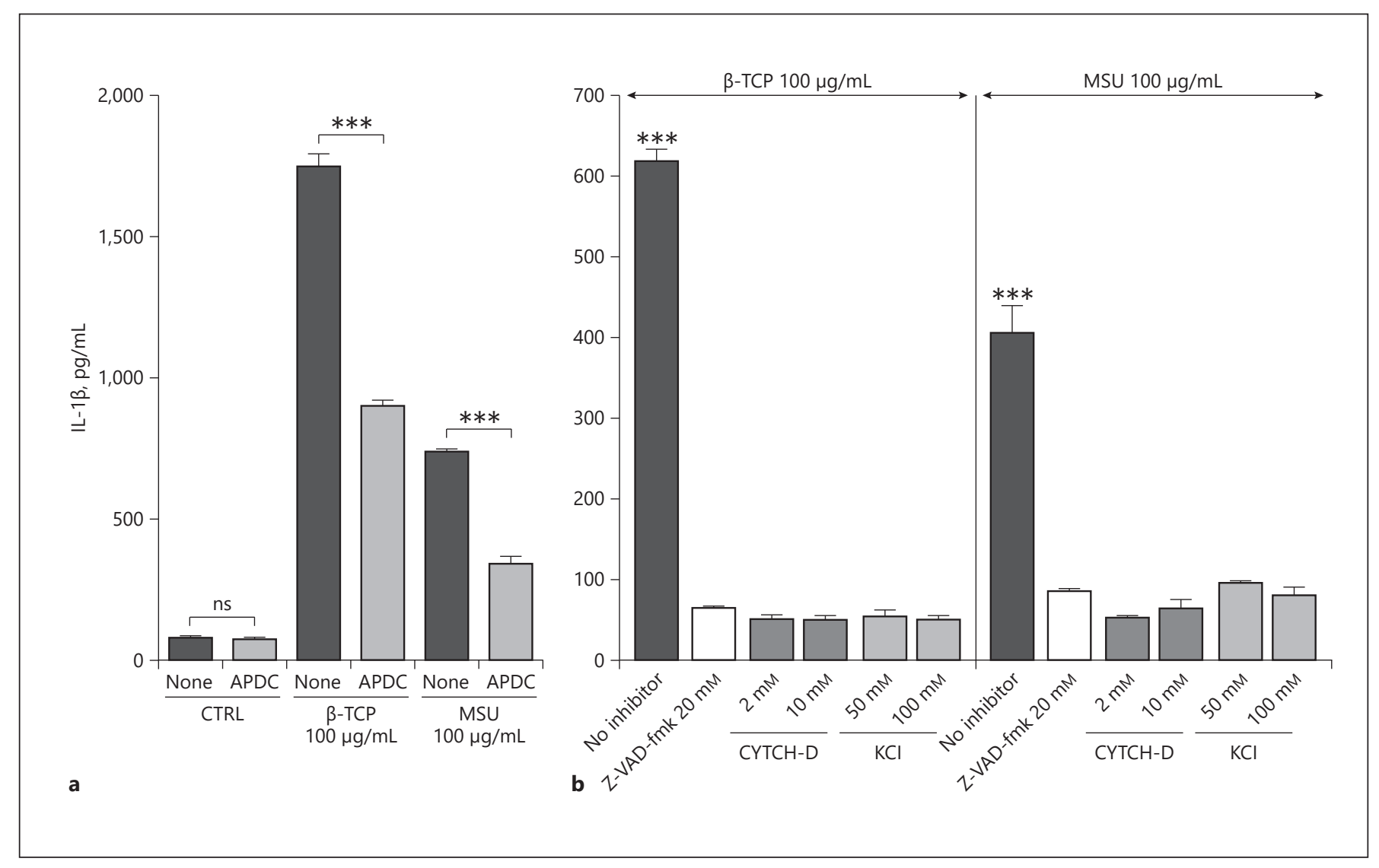

Fig. 6. Effects of inhibitors of ROS generation (a), potassium efflux and phagocytosis (b) on IL- $1 \beta$ production induced by $\beta$-TCP stimulation in human THP-1 cells. Human THP-1 cells were incubated with PMA and then stimulated with $100 \mu \mathrm{g} / \mathrm{mL}$ of $\beta$-TCP or MSU for $4 \mathrm{~h}$ with or without $100 \mu \mathrm{M}$ APDC (inhibitor of ROS generation), $100 \mathrm{mM} \mathrm{KCl}$ (potassium efflux inhibitor), or $2 \mathrm{mM}$ cytochalasin D (CYTCH-D; phagocytosis inhibitor). Inhibiting ROS generation (significantly $(p<0.001)$ attenuated $(\mathbf{a})$, whereas potas- sium efflux and phagocytosis inhibitors eliminated (b) IL-1 $\beta$ production. All treated groups significantly $(p<0.001)$ differed from control cells without inhibitor. Concentrations of IL-1 $\beta$ in supernatants were assayed by ELISA. Values are shown as means \pm SEM of triplicate values. ${ }^{*} p<0.001$; significantly different (Tukey tests). $\beta$-TCP, beta-tricalcium phosphate; MSU, monosodium urate; PMA, phorbol myristate acetate; APDC, 4-aminopyrrolidine-2,4dicarboxylic acid; SEM, standard error of the mean.

\section{Production of IL-1 $\beta$ Induced by $\beta-T C P$ in Genetically Modified THP-1 Sublines}

We investigated the effects of $\beta$-TCP on NLRP3 inflammasomes in the THP1-Null, THP1-defNLRP3, and THP1-defASC sublines derived from THP-1. Cells were differentiated into macrophages as described in the materials and methods and stimulated with $100 \mu \mathrm{g} / \mathrm{mL}$ of $\beta$-TCP or MSU. Both $\beta$-TCP and MSU induced a significant $(p<0.001)$ increase in IL- $1 \beta$ production in THP1Null cells (Fig 5b). However, IL- $1 \beta$ production was significantly lower $(p<0.001)$ in THP1-def ASC (def ASC) and THP1-defNLRP3 (def NLRP3) cells than in THP1Null cells incubated with $\beta$-TCP or MSU.
Activation of NLRP3 Inflammasome
Effect of Inhibition of Reactive Oxygen Species, Potassium Efflux, and Phagocytosis on $\beta$-TCPInduced IL-1 $\beta$ Production

The production of ROS, as well as potassium efflux, and phagocytosis are involved in inflammasome activation [28-37]. Differentiated THP-1 cells were incubated with $100 \mu \mathrm{g} / \mathrm{mL}$ of $\beta$-TCP or MSU with or without the ROS inhibitor APDC, 50 or $100 \mathrm{mM} \mathrm{K}$, and phagocytosis inhibitor cytochalasin-D. The findings showed that APDC significantly $(p<0.001)$ decreased IL- $1 \beta$ production induced by $\beta$-TCP or MSU (Fig. 6a). Cytochalasin-D and high concentrations of $\mathrm{K}^{+}$eliminated the prominent increase in IL- $1 \beta$ production induced by $\beta$-TCP or MSU $(p<0.001)$ (Fig. Fig. 6b). 


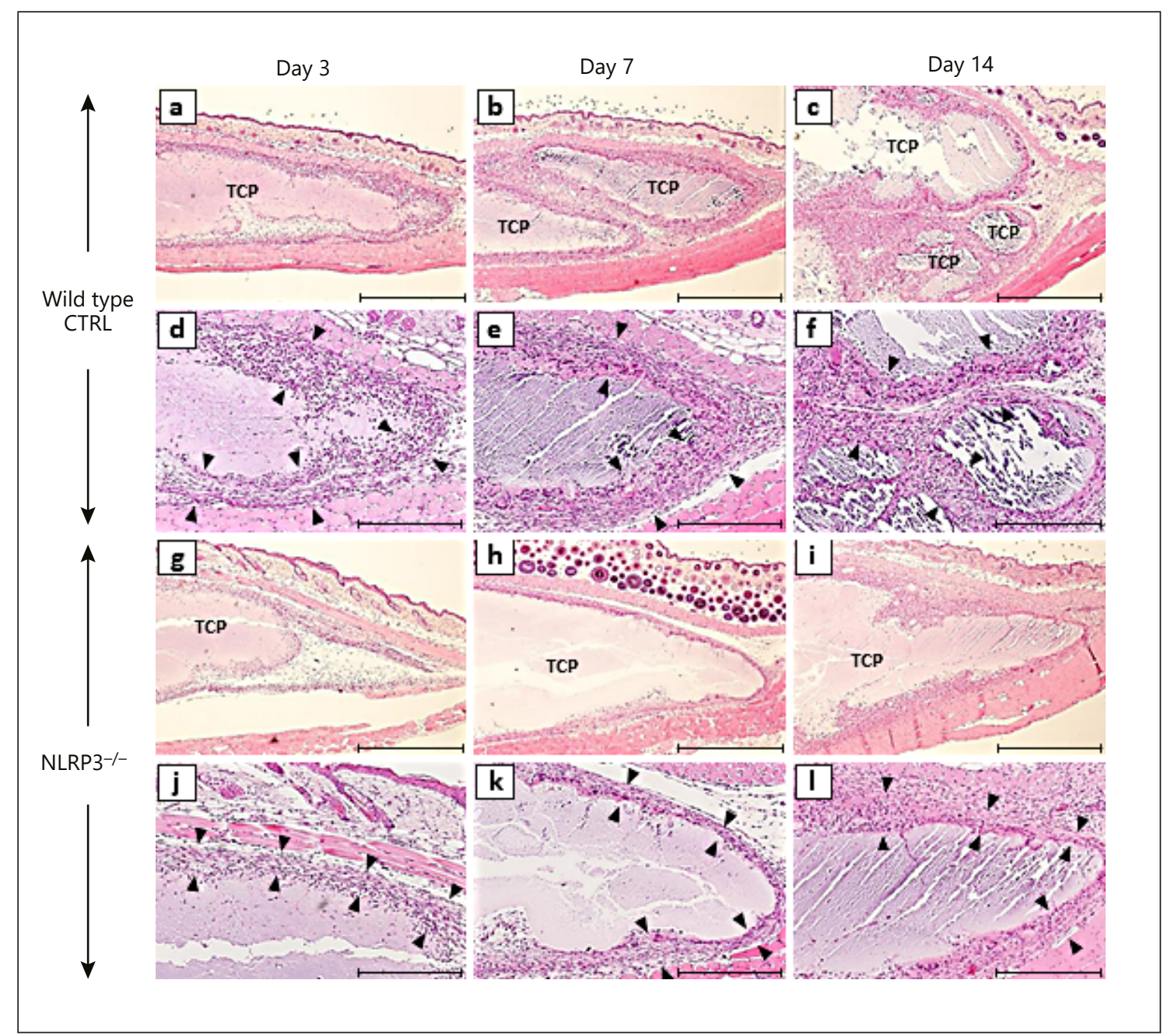

Fig. 7. Representative histological findings of mice injected with $\beta$-TCP. Wild-type and NLRP3-deficient littermate mice were subcutaneously injected with suspensions of fine $\beta$-TCP particles $(100$ $\mu \mathrm{g})$. Three, 7 , and 14 days later, tissue samples from areas surrounding $\beta$-TCP sites were collected and histologically analyzed.
Low $(\mathbf{a}-\mathbf{c}, \mathbf{g}-\mathbf{i})$ and high $(\mathbf{d}-\mathbf{f}, \mathbf{j}-\mathbf{I})$ magnification of sections stained with hematoxylin and eosin. $\mathbf{d}-\mathbf{f}, \mathbf{j}$-I Layer between 2 black arrows facing each other represents area of migrated immune cells. Scale bars, $250(\mathbf{a}-\mathbf{c}, \mathbf{g}-\mathbf{i})$ or $100(\mathbf{d}-\mathbf{f}, \mathbf{j}-\mathbf{I}) \mu \mathrm{m}$. $\beta$-TCP, beta-tricalcium phosphate.

\section{Effects of Subcutaneously Injecting $\beta$-TCP Particles} into Wild-Type or NLRP3-Deficient Mice in vivo

The experiments were performed using wild-type and NLRP3-deficient mice of littermates with the same genetic background. Suspensions of $\beta$-TCP particles in PBS were subcutaneously injected into the flanks of the mice and then tissue samples from areas surrounding the injection sites were excised from mice 3, 7, and 14 days later for histological assessment. We previously found abundant neutrophil migration around $\beta$-TCP particles 1 day after injection [23]. Two days later, the number of neutrophils had decreased, and small lymphocytes, histio- cytes, and fibroblasts predominated in tissues around the injection sites. Multinucleated giant cells appeared after 1 week [23]. The present histological findings were similar for wild-type mice, whereas the numbers of immune cells surrounding the injections sites was obviously decreased in NLRP3-deficient, compared with wild-type mice on days 3 (Fig. 7a, d vs. g, j), 7 (Fig. 7b, e vs. h, k), and 14 (Fig. 7c, f vs. i, l). The layer between the 2 black arrows facing each other represents an area of migrated immune cells (Fig. $7 \mathrm{~d}-\mathrm{f}, \mathrm{j}-\mathrm{l}$ ). Specimens from NLRP3-deficient mice had clearly thinner layers, indicating that fewer immune cells had migrated around implanted $\beta$-TCP. 


\section{Discussion}

The present study found that $\beta$-TCP was an activation signal for NLRP3 inflammasomes in mouse DCs and macrophages cultured with low doses of LPS and in human monocytic THP-1 cells. The prominent increase in IL-1 $\beta$ secretion induced by $\beta$-TCP was NLRP3-, ASC- (Fig. 5), and caspase-dependent (Fig. 3, 4) and also required phagocytosis, potassium efflux, and ROS generation (Fig. 6) like other inflammasome activators [25]. More IL-1 $\beta$ was secreted in cells incubated with $\beta$-TCP than in the positive control incubated with MSU (Fig. 2-6). Because the concentrations of $\beta$-TCP and MSU were the same in these experiments, differences in the size, shape, and/or numbers of $\beta$-TCP particles and MSU preparations might have affected the results. Fewer rod-shaped MSU crystals are found per unit weight than $\beta$-TCP particles. The secretion of IL- $1 \beta$ induced by $\beta$-TCP was eliminated in DCs derived from NLRP3-deficient mice, and the level of IL- $1 \beta$ was intermediate in DCs from NLRP3 heterozygous mice (Fig. 5a), suggesting that the number of NLRP3 molecules was decreased in NLRP3 heterozygous DCs compared to those in wild-type DCs. We found that $\beta$-TCP alone did not induce IL- $1 \beta$ secretion in primary cultured mouse DCs or macrophages (Fig. 1). Low-dose LPS is required to activate NLRP3 inflammasomes in these cells, suggesting that IL- $1 \beta$ secretion is strictly controlled under normal conditions. The first signal (low-dose LPS) induces pro-IL- $1 \beta$ synthesis, and the second ( $\beta$-TCP) triggers pro-IL- $1 \beta$ processing via caspase- 1 activation to form IL- $1 \beta$ p 17 [40].

Subcutaneously injected $\beta$-TCP induces extensive immune cell migration to areas surrounding injection sites [23]. We found abundant immune cell migration around $\beta$-TCP particles in wild-type mice, as previously reported. However, significantly fewer immune cells were recruited to $\beta$-TCP materials in NLRP3-deficient mice (Fig. 7). The NLRP3 inflammasomes play a crucial role in the immunostimulatory properties of aluminum adjuvants [43] as the mobilization of immune cells was significantly reduced in NLRP-, ASC-, and caspase-1-deficient, compared with wild-type mice intraperitoneally injected with aluminum adjuvants. Activating NLRP3 inflammasomes might play a crucial role in the recruitment of immune cells and other activities induced by $\beta$-TCP in vivo.

A critical role of ASC in the activation of NLRP3 and AIM2 inflammasomes has recently been determined. During inflammasome activation, ASC becomes phos- phorylated dependently on spleen tyrosine kinase, mitogen-activated protein kinase 8 , and mitogen-activated protein kinase 9 [44] and it also forms cytosolic macromolecular aggregates called ASC specks [34, 45]. Phosphorylation of Tyr144 in mouse ASC is critical for speck formation and caspase-1 activation [44]. We found significantly reduced IL- $1 \beta$ secretion in THP-1 cells, deficient in either NLRP 3 or ASC but less IL- $1 \beta$ was secreted in ASC-deficient cells (Fig. 5). Another protein might have partially compensated for the loss of NLRP3 from inflammasome complexes in NLRP3 deficient cells, and ASC and ASC specks are indispensable in complexes such as NLRP3 and AIM2 inflammasomes containing ASC.

Overall, the present results showed that $\beta$-TCP particles activated NLRP3 inflammasomes in the presence of low-dose LPS as a first signal. This activation was dependent on caspase, phagocytosis, potassium efflux, and ROS generation. However, several issues, such as the effect of calcium ions that released from calcium ceramic particles incorporated into immune cells on NLRP3 inflammasome, remain to be elucidated. Further studies are required to validate $\beta$-TCP as a prospective immunomodulator.

\section{Acknowledgements}

The authors would like to express our sincere gratitude to Dr. Sachiko Tai for making a great contribution to the execution of the experiment. The authors thank Dr. Masatoshi Kusuhara of the Regional Resources Division; Dr. Ken-ichi Urakami, Dr. Shumpei Ohnami, and Dr. Sumiko Ohnami of the Cancer Diagnostics Research Division of Shizuoka Cancer Center Research Institute; and Dr. Tetsuro Ogawa and Dr. Hiraku Inoue of Olympus Terumo Biomaterials Corporation for collaboration and technical support.

\section{Statement of Ethics}

The animal experiment protocols were reviewed and approved by the Animal Experiment Ethics Committee of the Shizuoka Cancer Center Research Institute, approval number: 28-4. All mice were housed and manipulated according to the standard ethical guidelines for the care and use of laboratory animals (Science Council of Japan; Guidelines for Proper Conduct of Animal Experiments, 2006). For the experiments using human materials in this study, no ethics approval was required as it was performed in vitro using cell line and no primary human samples were used.

\section{Conflict of Interest Statement}

The authors have no conflicts of interest to declare. 


\section{Funding Sources}

This work was supported by JSPS KAKENHI (Grant nos.: 26350524 and 18K12094).

\section{Author Contributions}

K.M. designed the study, conducted experiments, analyzed data, and wrote the manuscript. J.-Y.C. and Y.T. conducted experiments using primary cultured cells in vitro. Y.T. and V.Z. conducted experiments using THP-1 cells in vitro. H.I. conducted the animal experiments. T.S. and T.H. contributed to the preparation and granulometric analysis of the $\beta$-TCP particles. J.-Y.C. and H.I. conducted histological analyses. K.Y. contributed to the management and funding of the study.

\section{Data Availability Statement}

The numerical data that support the findings of this study are included in this article and its online suppl. files. Further enquiries can be directed to the corresponding author.

\section{References}

1 Zerbo IR, Zijderveld SA, de Boer A, Bronckers AL, de Lange G, ten Bruggenkate CM, et al. Histomorphometry of human sinus floor augmentation using a porous beta-tricalcium phosphate: a prospective study. Clin Oral Implants Res. 2004;15(6):724-32.

2 Zijderveld SA, Zerbo IR, van den Bergh JP, Schulten EA, ten Bruggenkate CM. Maxillary sinus floor augmentation using a beta-tricalcium phosphate (Cerasorb) alone compared to autogenous bone grafts. Int J Oral Maxillofac Implants. 2005;20(3):432-40.

3 Zerbo IR, Bronckers AL, de Lange G, Burger $\mathrm{EH}$. Localisation of osteogenic and osteoclastic cells in porous beta-tricalcium phosphate particles used for human maxillary sinus floor elevation. Biomaterials. 2005;26(12):144551.

4 Nolff MC, Kokemueller H, Hauschild G, Fehr M, Bormann KH, Spalthoff S, et al. Comparison of computed tomography and microradiography for graft evaluation after reconstruction of critical size bone defects using betatricalcium phosphate. J Craniomaxillofac Surg. 2010;38(1):38-46.

5 Stavropoulos A, Windisch P, Szendröi-Kiss D, Peter R, Gera I, Sculean A. Clinical and histologic evaluation of granular beta-tricalcium phosphate for the treatment of human intrabony periodontal defects: a report on five cases. J Periodontol. 2010; 81(2):325-34.

6 Ghanaati S, Barbeck M, Orth C, Willershausen I, Thimm BW, Hoffmann C, et al. Influence of $\beta$-tricalcium phosphate granule size and morphology on tissue reaction in vivo. Acta Biomater. 2010;6(12):4476-87.

7 Velard F, Braux J, Amedee J, Laquerriere P. Inflammatory cell response to calcium phosphate biomaterial particles: an overview. Acta Biomater. 2013;9(2):4956-63.

8 Nery EB, LeGeros RZ, Lynch KL, Lee K. Tissue response to biphasic calcium phosphate ceramic with different ratios of HA/beta TCP in periodontal osseous defects. J Periodontol. 1992;63(9):729-35.

9 Accorsi-Mendonça T, Conz MB, Barros TC, de Sena LA, de Almeida Soares G, Granjeiro
JM. Physicochemical characterization of two deproteinized bovine xenografts. Braz Oral Res. 2008;22(1):5-10.

10 Daculsi G, Legeros JP. Three-dimensional defects in hydroxyapatite of biological interest. J Biomed Mater Res. 1996;31(4):495-501.

11 Prudhommeaux F, Schiltz C, Lioté F, Hina A, Champy R, Bucki B, et al. Variation in the inflammatory properties of basic calcium phosphate crystals according to crystal type. Arthritis Rheum. 1996;39(8):1319-26.

12 Daculsi G, Passuti N. Effect of the macroporosity for osseous substitution of calcium phosphate ceramics. Biomaterials. 1990;11: 86-7.

13 Malard O, Bouler JM, Guicheux J, Heymann $\mathrm{D}$, Pilet $\mathrm{P}$, Coquard $\mathrm{C}$, et al. Influence of biphasic calcium phosphate granulometry on bone ingrowth, ceramic resorption, and inflammatory reactions: preliminary in vitro and in vivo study. J Biomed Mater Res. 1999; 46(1):103-11.

14 Goyal AK, Rawat A, Mahor S, Gupta PN, Khatri K, Vyas SP. Nanodecoy system: a novel approach to design hepatitis B vaccine for immunopotentiation. Int J Pharm. 2006; 309(1-2):227-33.

15 Ramesh M, Turner LF, Yadav R, Rajan TV, Vella AT, Kuhn LT. Effects of the physicochemical nature of two biomimetic crystals on the innate immune response. Int Immunopharmacol. 2007;7(13):1617-29.

16 Ciocca DR, Frayssinet P, Cuello-Carrión FD. A pilot study with a therapeutic vaccine based on hydroxyapatite ceramic particles and selfantigens in cancer patients. Cell Stress Chaperones. 2007;12(1):33-43.

17 Goyal AK, Khatri K, Mishra N, Mehta A, Vaidya B, Tiwari S, et al. Development of selfassembled nanoceramic carrier construct(s) for vaccine delivery. J Biomater Appl. 2009; 24(1):65-84

18 Abei M, Okumura T, Fukuda K, Hashimoto $\mathrm{T}$, Araki M, Ishige $\mathrm{K}$, et al. A phase I study on combined therapy with proton-beam radiotherapy and in situ tumor vaccination for locally advanced recurrent hepatocellular carcinoma. Radiat Oncol. 2013;8:239.
19 Marconato L, Frayssinet P, Rouquet N, Comazzi S, Leone VF, Laganga P, et al. Randomized, placebo-controlled, double-blinded chemoimmunotherapy clinical trial in a pet dog model of diffuse large B-cell lymphoma. Clin Cancer Res. 2014;20(3):668-77.

20 Chua BY, Sekiya T, Al Kobaisi M, Short KR, Mainwaring DE, Jackson DC. A single dose biodegradable vaccine depot that induces persistently high levels of antibody over a year. Biomaterials. 2015;53:50-7.

21 Hayashi M, Aoshi T, Kogai Y, Nomi D, Haseda Y, Kuroda E, et al. Optimization of physiological properties of hydroxyapatite as a vaccine adjuvant. Vaccine. 2016;34(3):30612.

22 Wang X, Li X, Ito A, Watanabe Y, Sogo Y, Hirose $M$, et al. Rod-shaped and substituted hydroxyapatite nanoparticles stimulating type 1 and 2 cytokine secretion. Colloids Surf B Biointerfaces. 2016;139:10-6.

23 Tai S, Cheng JY, Ishii H, Akimoto S, Satoh T, Yamamoto K, et al. Characterization of beta-tricalcium phosphate as a novel immunomodulator. Int Immunopharmacol. 2014;19(1):45-51.

24 Tai S, Cheng JY, Ishii H, Shimono K, Zangiacomi V, Satoh T, et al. Effects of beta-tricalcium phosphate particles on primary cultured murine dendritic cells and macrophages. Int Immunopharmacol. 2016;40:419-27.

25 Schroder K, Tschopp J. The inflammasomes. Cell. 2010;140(6):821-32.

26 Lamkanfi M, Dixit VM. Mechanisms and functions of inflammasomes. Cell. 2014; 157(5):1013-22.

27 Elinav E, Strowig T, Henao-Mejia J, Flavell RA. Regulation of the antimicrobial response by NLR proteins. Immunity. 2011;34(5):665-79.

28 Halle A, Hornung V, Petzold GC, Stewart CR, Monks BG, Reinheckel T, et al. The NALP3 inflammasome is involved in the innate immune response to amyloid-beta. Nat Immunol. 2008;9(8):857-65.

29 Hornung V, Bauernfeind F, Halle A, Samstad EO, Kono H, Rock KL, et al. Silica crystals and aluminum salts activate the NALP3 inflammasome through phagosomal destabilization. Nat Immunol. 2008;9(8):847-56. 
30 Dostert C, Pétrilli V, van Bruggen R, Steele C, Mossman BT, Tschopp J. Innate immune activation through Nalp3 inflammasome sensing of asbestos and silica. Science. 2008; 320(5876):674-7.

31 Gross O, Poeck H, Bscheider M, Dostert C, Hannesschläger N, Endres S, et al. Syk kinase signalling couples to the Nlrp3 inflammasome for anti-fungal host defence. Nature. 2009;459(7245):433-6.

32 Pétrilli V, Papin S, Dostert C, Mayor A, Martinon F, Tschopp J. Activation of the NALP3 inflammasome is triggered by low intracellular potassium concentration. Cell Death Differ. 2007;14(9):1583-9.

33 Shio MT, Tiemi Shio M, Eisenbarth SC, Savaria $\mathrm{M}$, Vinet $\mathrm{AF}$, Bellemare $\mathrm{MJ}$, et al. Malarial hemozoin activates the NLRP3 inflammasome through Lyn and Syk kinases. PLoS Pathog. 2009;5(8):e1000559.

34 Fernandes-Alnemri T, Wu J, Yu JW, Datta P, Miller B, Jankowski W, et al. The pyroptosome: a supramolecular assembly of ASC dimers mediating inflammatory cell death via caspase-1 activation. Cell Death Differ. 2007; 14(9):1590-604.
35 Franchi L, Kanneganti TD, Dubyak GR, Núñez G. Differential requirement of P2X7 receptor and intracellular $\mathrm{K}+$ for caspase- 1 activation induced by intracellular and extracellular bacteria. J Biol Chem. 2007;282(26):18810-8.

36 Cassel SL, Eisenbarth SC, Iyer SS, Sadler JJ, Colegio OR, Tephly LA, et al. The Nalp3 inflammasome is essential for the development of silicosis. Proc Natl Acad Sci U S A. 2008; 105(26):9035-40.

37 Cruz CM, Rinna A, Forman HJ, Ventura AL, Persechini PM, Ojcius DM. ATP activates a reactive oxygen species-dependent oxidative stress response and secretion of proinflammatory cytokines in macrophages. J Biol Chem. 2007;282(5):2871-9.

38 Jin C, Frayssinet P, Pelker R, Cwirka D, Hu B, Vignery A, et al. NLRP3 inflammasome plays a critical role in the pathogenesis of hydroxyapatite-associated arthropathy. Proc Natl Acad Sci U S A. 2011;108(36):14867-72.

39 Ea HK, Chobaz V, Nguyen C, Nasi S, van Lent P, Daudon M, et al. Pathogenic role of basic calcium phosphate crystals in destructive arthropathies. PLoS One. 2013;8(2):e57352.

40 Pazár B, Ea HK, Narayan S, Kolly L, Bagnoud $\mathrm{N}$, Chobaz V, et al. Basic calcium phosphate crystals induce monocyte/macrophage IL- $1 \beta$ secretion through the NLRP3 inflammasome in vitro. J Immunol. 2011;186(4):2495-502.
41 Srinivasula SM, Poyet JL, Razmara M, Datta $\mathrm{P}$, Zhang Z, Alnemri ES. The pyrin-CARD protein ASC is an activating adaptor for caspase-1. J Biol Chem. 2002;277(24):21119-22.

42 Martinon F, Burns K, Tschopp J. The inflammasome: a molecular platform triggering activation of inflammatory caspases and processing of proIL-beta. Mol Cell. 2002;10(2): 417-26.

43 Eisenbarth SC, Colegio OR, O'Connor W, Sutterwala FS, Flavell RA. Crucial role for the Nalp3 inflammasome in the immunostimulatory properties of aluminium adjuvants. $\mathrm{Na}$ ture. 2008;453(7198):1122-6.

44 Hara H, Tsuchiya K, Kawamura I, Fang R, Hernandez-Cuellar E, Shen Y, et al. Phosphorylation of the adaptor ASC acts as a molecular switch that controls the formation of speck-like aggregates and inflammasome activity. Nat Immunol. 2013;14(12):1247-55.

45 Bryan NB, Dorfleutner A, Rojanasakul Y, Stehlik C. Activation of inflammasomes requires intracellular redistribution of the apoptotic speck-like protein containing a caspase recruitment domain. J Immunol. 2009; 182(5):3173-82. 